Vol. 7, No. 1, 2021

Viktor Proskuryakov ${ }^{1}$, Serhii Ivanov-Kostetskyy ${ }^{2}$, Adrian Fitio ${ }^{3}$, Mariia Anisimova ${ }^{4}$

\title{
ARCHITECTURAL, ECONOMIC, AND MENTAL FACTORS OF THE REVIVAL OF HISTORICAL INDUSTRIAL FACILITIES IN THE CONTEXT OF THE FORMATION OF TERRITORIAL COMMUNITIES OF UKRAINE (ON THE EXAMPLE OF THE RENOVATION OF A SALT FACTORY IN DROHOBYCH)
}

\author{
${ }^{I}$ Professor, Sc.Dr., Head of the Department of Architectural Environment Design. \\ Lviv Polytechnic National University, Lviv \\ e-mail: viktor.i.proskuriakov@1pnu.ua \\ orcid: 0000-0003-1022-8984 \\ ${ }^{2}$ PhD, Department of Architectural Environment Design \\ Lviv Polytechnic National University, Lviv \\ e-mail: serhii.o.ivanov-kostetskyi@lpnu.ua \\ orcid: 0000-0002-6047-609X \\ ${ }^{3}$ NGO "AC "EXPERT-GROUP" \\ e-mail: expertlviv@gmail.com \\ ${ }^{4}$ PhD, Department of Business Economics and Investment \\ Lviv Polytechnic National University, Lviv \\ e-mail: mariia.v.anisimova@lpnu.ua \\ orcid: 0000-0002-1447-0930
}

Received: 25.02.2021 / Revised: 09.04.2021 / Accepted: 27.04.2021

(C) Proskuryakov V., Ivanov-Kostetskyy S., Fitio A., Anisimova M., 2021

https://doi.org/10.23939/as2021.01.066

Astract. The article highlights the path and factors influencing the revival of historical sites on the example of the renovation of a salt factory in Drohobych.

Key words: architectural, economic, mental factors; revival; historical, typical, unified, serial, industrial buildings of Drohobych.

\section{Problem statement}

In the late XX and early XXI centuries, scientists predicted that even with the deepening processes of globalization in the world and the strengthening of the distribution of production between countries, certain types of production will always be in the cities of each country. These are the food industry, heat and energy supply, housing construction, waste processing, repair and maintenance industries.

The leading industrial enterprises of the XXI century should exclusively become enterprises of a new generation and represent not a separate unit that produces products, but an integrated component in the 
overall structure of relations - Raw Materials, Market, Energy, Economic, etc. Marketing, research, technical development, quality control, product and resource allocation, strategic planning and human resource redistribution will be integral functions of such enterprises. All this will preserve the phenomena of cities that are thousands of years old and will not allow cities to dissolve into settlements. (Vershinin V., 2006, p. 135)

Other scientists argue that modern cities cannot live and develop without spiritual culture, the constant development of cultural and educational institutions, cinemas, libraries, theatres, museums, concert halls, cultural parks. They say that the main issue in cities remains the organization of effective use of free time, which is a "friend" of their residents. (Bouryak A., Lombardini N., 2015, p. 25-28)

A special place is occupied by scientists' research on the phases of urban life cycles. In their opinion, cities go through 4 phases of development (intensive growth), growth (it slows down), stagnation and decline. In each of these states of the city, along with all other city-forming factors, the most important one is the factor of jobs, and therefore city-forming enterprises.

It all starts from the phase when this factor is provided by investment, a shortage of jobs, the volume of life benefits per capita, an increase in housing construction, and so on. Undoubtedly, this state cannot be endless and the city naturally, and sometimes spontaneously, goes into a phase of growth, which is gradually slowed down. And later in the phase of stagnation (when the state of the city is affected by the gap between the number of jobs and the volume of housing stock, and living well-being reaches such a level that population growth due to migration stops). And over time, there comes a phase of decline, that is when life in the city becomes uncomfortable. This is caused by poor housing conditions, low levels of affluence, unfavourable environmental conditions, lack of employment prospects, which affects job cuts, and this is the way to outflow the population. Because the ageing of industrial enterprises, or the depletion of resources at mining enterprises, leads to a catastrophic deterioration of the urban environment. The city can be in an extremely difficult situation and become depressed. (Dorofeyeyv V., Nikiforova R., 2015, p. 25-28) A city can become like this not because of stagnation and destruction of cultural values, objects or heritage, but because of industrial facilities. This aspect of the life of modern cities is studied both by foreign scientists and in the post-Soviet countries and in particular in Ukraine, which from the previous ideological formation and during the transition to a market economy inherited thousands of square kilometres of degraded industrial territories and thousands of industrial buildings with backward technologies with increased resource capacity. (Proskuryakov, Ivanov-Kostetsky, 2016, P. 120) Such cities in Ukraine, among others, include the city of Drohobych, in which the main city-forming enterprises have ceased their activities or are operating in incomplete volume, as well as in neighbouring cities that formed a unique agglomeration in the west of Ukraine - Boryslav, Stebnik, Truskavets and others. These are competitive enterprises that were noticeable at the state level in the former USSR: Drohobych automobile crane plant, Chisel plant, Drohobych paint, Stebnytske, Polymineral, Granit plant in Borislav, etc. Restoration and reconstruction of historical cities after military destruction, changes in the professional activities of residents in other countries is recognized as one of the priority areas of architectural activity. This was also a component of both restoration and expansion of the functions of historical buildings, which are actively involved in the modern life of the city and enriched with new modern functions. For this purpose, the necessary technical measures are carried out, leading to alterations, partial demolition, and highlighting of the most interesting elements and fragments of architectural monuments in the reconstructed part of the building. The buildings have a renovation, revalorization of territories and the environment of complexes and ensembles in which these buildings exist.

This fully applies to objects of industrial architecture as well. Since the 70-80s of the twentieth century, this activity of renovation of industrial architecture objects has been widely used in foreign architectural practice. The most famous examples of this include the transformation of the industrial complex of gas tanks in Vienna (years of construction 1896-1899) into a modern residential, shopping and office centre. In the design and reassignment, two architects took part: J. Nouvel, who designed housing in one of the gas tanks, and V. Prince, who proposed an additional modern block for the new office in one of 
the gas tanks, which seemed to be right next to the historical structure. The Wehdorn Architects group and V. Holzbauer also implemented their ideas in this complex, turning an industrial historical building into a world masterpiece. There are many such examples of renovation of historical industrial facilities in foreign architectural practice: in the factory buildings of 1918, German architects created the Center for media technologies in Karlsruhe (Germany) at the end of the twentieth century. (Cherkasova E., Lopatko V., Lombardini N., 2015, p. 18-50) Lots of buildings became world-famous: library and studios in the tram depot of Amsterdam; "green" offices in a former factory in Montreal; a student dormitory in a former grain elevator in Oslo; the Maritime Museum in the hangar of seaplanes built in the early twentieth century, in Tallinn; the multifunctional centre "Manufactory" in the buildings of a textile factory constructed in 1874-1878 in Lodz; the Center for the modern culture of Lisbon in factory premises, etc. There are also examples in Ukraine: The Exhibition Center for Contemporary Art in the former Arsenal factory in Kyiv, a multifunctional complex of offices, housing, and retail establishments in the space of the former Kinescope factory in Lviv.

In Drohobych, Stebnik, Borislav there are historical industrial enterprises known all over the world. First of all, there are a salt factory, a meat processing plant, an oil refining complex "Polmin" (now "Galicia"), office buildings at enterprises, railway stations and other structures on the railway, etc. These cities should also become coordinates for finding areas of renovation, revalorization, rehabilitation, and preserved monuments of industrial architecture. This is required by the general socio-economic changes in Ukrainian society. Changes that led to the redistribution of urban functions, the need to find a new use for industrial buildings due to changes in industrial technologies, the closure of production facilities, and other reasons. These and other problematic issues raised related to effective regional management, effective development of both urbanized and rural areas, led to a large-scale reform of local selfgovernment and territorial organization of power in Ukraine, which began in the spring of 2014. (KMU 2020) In fact, the reform was intended to carry out a total dismantling of the rigid vertical of public administration of communities, allowing them to independently determine architectural-spatial, investment, economic and social policies. Thus, starting from 2020, the borders of Drohobych, Boryslav, and Truskavets territorial communities have changed on an extremely large scale. (https://decentralization.gov.ua/newrayons/1362/communities) In particular, geographically the Drohobych community united 34 localities, including the city of Drohobych and the city of Stebnik, while the area increased almost 10 times from $44.5 \mathrm{~km}^{2}$ to $420.7 \mathrm{~km}^{2}$.

Table 1

Actual parameters of territorial communities as of 01.01.2021

\begin{tabular}{|c|c|c|c|}
\hline Name of the territorial community & Number of people & Area, km.sq. & Number of localities \\
\hline Drohobych & 122,905 & 420.7 & 34 \\
\hline Truskavets & 39642 & 214.8 & 8 \\
\hline Boryslav & 39526 & 161.8 & 7 \\
\hline Skhidnytsa & 16489 & 420 & 22 \\
\hline Total & 218,562 & 1217 & 71 \\
\hline
\end{tabular}

In addition to the territorial organization of power, approaches to financing projects related to ensuring the life of the community and its economic development have radically changed. (Mizina I. 2016) At this stage, careful attention should be paid to architectural and spatial planning, since the optimal use of limited financial resources of the community depends on a rational and pragmatic approach to the use of objects. It is important to use the existing "branded" (salt factory) or old industrial (Drohobych chisel, paint and varnish factory, etc.) objects, adapting them to the conditions of the present. This is important in several aspects, one of which is filling the revenue side of local budgets. For example, 
the Drohobych community with a total budget of $\mathbf{Z} 805.0$ million receives an additional basic subsidy from the state budget in the amount of z101.4 million (which is $12.6 \%$ ), because they cannot cover the costs of its existence on its own.

\section{Purpose of the article}

The article highlights the path and factors influencing the revival of historical sites on the example of the renovation of a salt factory in Drohobych. Urban Development Strategies.

\section{Results and discussion}

On December 8-17, 2020, the seminar "Magical salt cities" was held in Ukraine. Renovation of salt factories as a strategy for urban development in Ukraine and Germany. The initiators of the seminar were Professor, Detlef Kurt, PhD, master Kuzishin Anna from the Technical University of Kaiserslautern, Faculty of Spatial Planning. Partners and managers in Ukraine are professors, Cherkess Bogdan, $\mathrm{PhD}$ and Proskuryakov Viktor, PhD, and masters of architecture Bogdanova Yulia and Kopylyak Igor from the Institute of Architecture and Design, students and experts in the field of Architecture, Urban Planning, Urban Management, Economics, Ecology and Geography (A. Fityo, M. Anisimova, etc.), who developed the concept of the seminar its purpose and objectives. The seminar was held at the Department of Architectural Environment Design not only because since its inception in 2003 it has been one of the few that cultivates various forms of educational and applied training of students in Ukraine, an important component of which has been futuristic projects tested in international and national student design seminars and competitions. (Proskuryakov, 2013, p. 92-98) Moreover, the department, among others, had such projects - "Sketch-idea of the city of the future Prykarpatska", "Sketch-idea of humanization of the centre of Borislav", the theme of which was the development in the future of the cities of Drohobych, Stebnik, Truskavets, Borislav (Proskuryakov V., 2019, p. 50-62), (Fityo A., 2019)

Table 2

\section{Revenue parts of local budgets of territorial communities and transfers from the state budget as of 01.01.2021}

\begin{tabular}{|l|c|c|c|}
\hline Name of the territorial community & $\begin{array}{c}\text { Total budget revenues, } \\
\text { mln. } \mathbf{z .}\end{array}$ & Basic grant, mln. $\mathbf{z .}$ & $\begin{array}{c}\text { Share of basic } \\
\text { subsidies in total } \\
\text { budget revenues, } \\
\%\end{array}$ \\
\hline Drohobych & 805.6 & 101.4 & $12.6 \%$ \\
\hline Truskavets & 270.0 & 5.7 & $2.1 \%$ \\
\hline Boryslav & 367.6 & 17.2 & $4.7 \%$ \\
\hline Skhidnytsa & 115.1 & 22.1 & $19.2 \%$ \\
\hline Total & 1558 & 146 & - \\
\hline
\end{tabular}

The choice of Drohobych city for the seminar by colleagues from the German university and its historical industrial salt facility was not accidental. The Drohobych salt factory is a similar enterprise to the one in Kaiserslautern in Germany, which is one of the oldest in Europe. Both the first and second enterprises formed the so-called "Salt route" along which, for example, merchants from different regions of Eastern Europe - Podillia, Bratslav region, Kholm region, Volhynia - were arriving for Drohobych salt. They were coming from the Volyn piers along the Sluch and Goryn rivers, and then along the Dnipro river to Kyiv. In the final version of the seminar, all activities were directed to Drohobych and its facility (Fig. 1). Although, initially, the seminar was supposed to be held in both the above-mentioned cities of Ukraine and Germany. With the exchange of student project groups with their managers, who were 
supposed to get acquainted with both the space and environment of enterprises, their technologies, the composition of industrial buildings, and with the history, genesis and development of industry in Kaiserslautern and Drohobych, their culture and contribution to the development of European and world human civilization. But in the context of the Covid-19 pandemic, which the organizers encountered during the seminar, it made it impossible to implement it in Germany. Therefore, it was decided to concentrate all activities in Ukraine, in Drohobych. Also, it was decided to conduct the exchange of information (about previous surveys of the Drohobych salt factory and other industrial facilities, about historical events in the city and its origin, personalities that formed the intellectual potential of the city and region, and the design itself) online.

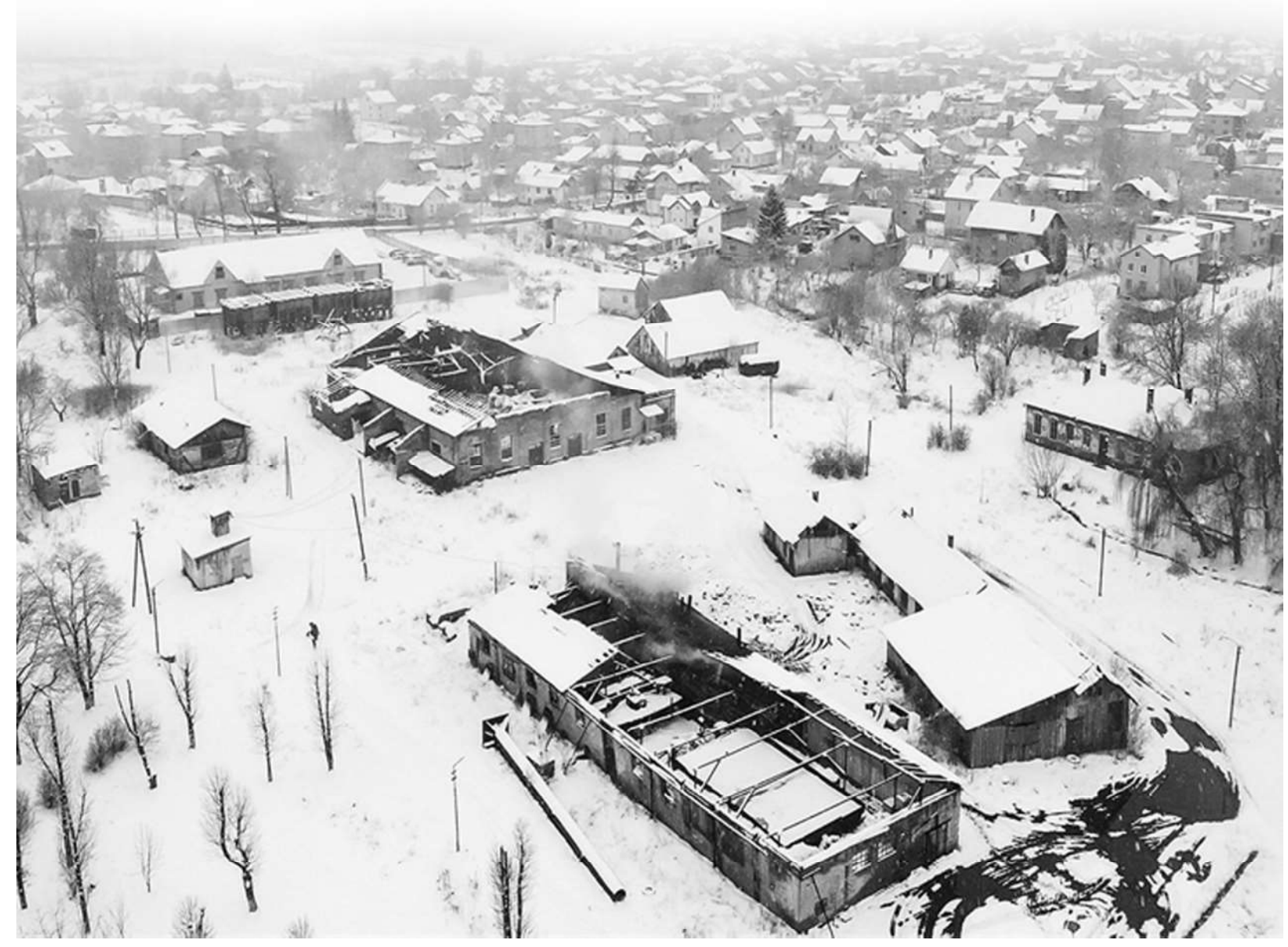

Fig. 1. Helicopter perspective of the "romantic" ruins of a salt factory in Drohobych.

Photo by R. Demkiv

During the design and training seminar "Magical salt cities" in Drohobych, its leaders planned to solve not only the architectural and spatial problems of this city. First of all, the task was to teach students that they should never randomly use the postulates of their architectural schools and their restrictive norms, but conduct bold searches and learn to analyze the complex realities of a problem city to find ways to environmental, plastic, and effective beauty. They should learn that it is impossible to constantly seek compromises, as practice architects do, which leads to extremely formalistic solutions because these solutions must always be different depending on the tasks. Students should know that architecture that does not belong to the modern era (based on constant principles and laws of balance and harmony) can also give life to modern new plastic forms, condense or vice versa dilute and that it should be in the design process itself, a process that develops from the past to the future. 
The workshop was supposed to be a kind of experiment within an experiment. For this purpose, all participants of the seminar from Ukraine and Germany were divided into four teams. Although most of the students were fluent in English, the difficulty was different - they had to start working immediately after the first minutes of acquaintance and in spontaneously formed teams. Besides, the seminar participants studied at universities that are representatives of different architectural schools and applied different approaches to the revitalization of the Drohobych salt factory. The proposals were very different because the participants were urbanists (in particular, students from Germany) and representatives of the Department of Architectural Environment Design of the Lviv Polytechnic National University. It was necessary to solve problems of urban planning, complete tasks related to landscape and volume design, environmental design, and so on. There was a hope that this variety would give a positive result, which, in the future, could be used to solve real problems.

After students and their supervisors got familiar with the existing buildings in which the main technological operations take place (buildings above the brine mine; buildings with a pump for brine; buildings with brine settling tanks; buildings in which there are bowls for boiling salt and furnaces under them for evaporating salt; administration buildings and warehouses; ruins on the site of the projected "new buildings"), the seminar vector has changed. The change was also influenced by the fact that the territory of the salt factory, which was formed for hundreds of years and stabilized in the last years of the XXI century, began the process of haphazard "biting off" plots for a supermarket, shop, primitive metal garages without taking into account the peculiarities of the genesis and development of such an industry in Drohobych, which operated at least from the XIV century (maybe even earlier). The seminar in Drohobych was originally planned exclusively as work on the revitalization of the salt factory. But a detailed review on the condition of the buildings, technology and territory of the plant made it clear that the industrial enterprise, which is one of the oldest in Eastern Europe, will not be able to work effectively, performing only one historical function - salt extraction. Therefore, the main focus of the seminar was to identify and implement additional functions at the facility that were based on the history of the city and region. A typical solution to this problem could be the implementation of a corresponding investment project within various types of capital construction - expansion, reconstruction or technical re-equipment of the enterprise. Such decisions fundamentally change the entire reproductive structure of the main ones, as a result of which conditions are provided for the continuation of the enterprise's activities.

However, as practice and the results of our research show, these measures are often not enough, they need to be supported by additional ones: diversification of production and manufacturing of new products; manufacturing of traditional but innovative products, etc. In other words, all these measures, as a rule, relate to two types of reproduction - investment and innovation.

Innovative reproduction is a relatively new term that shows that reproduction occurs on a fundamentally new basis - technological and organizational, management and information, supply and sales, financial and economic, etc., the main element of which is considered to be the formation of economic profit (super-profit). This type of reproduction is not fundamentally new for the Ukrainian economy, since it is used at domestic enterprises. (Anisimova M., 2018, p. 451-452) Participants of the cross-cultural project on the example of a salt factory had to offer a wide range of solutions that would have the potential for further development and answer the question: What should be the public environment in an industrial territory, what architectural language should be chosen for such an important historical object? The seminar was supposed to answer these and other questions and reveal the prospects not only for the revitalization of the Drohobych salt factory but also try to answer the general question of how the city of Drohobych can develop infrastructurally and structurally in the future.

For this purpose, all students participating in the seminar (11 from Lviv and 8 from Kaiserslautern) were organized into four teams, each of which explored a certain vector of problems, the solution of which formed the foundation on which search design was based later. One of them is under the slogan "Salt Roads" consisting of Yu. Yanul, A. Vovk, A. Dereshevska, Zoë Röstel and D. Thress explored cities and places of salt mining in Drohobych region and even in Transcarpathia. Such cities, in addition to 
Drohobych, were the following: Mykolayiv, Medenychi, Stebnyk, Modrychi Truskavets, Boryslav, Yasenytsa-Silna, Stara-Sil and other. The second group, united under the slogan "Golden Triangle", consisting of O. Zayets, S. Zhantalay, Ya. Kudri, M. Jendretzke, L. Bruss, studied the industry of the Drohobych-Stebnyk-Truskavets-Boryslav agglomeration. Another group of students united under the slogan "Drohobych - Republic Of Dreams", consisting of A.-M. Makaryk, V.-M. Nahirnyak, A. Kalinichenko, T. Mühchow, J. Weinkauf explored the cultural potential of the agglomeration. And the last group - O. Boyko, K. Ivashchuk, A. Kushnir, T. Schneider, - in a group called "The Healing Power of Salt", analyzed the possibilities of salt as a component of treatment in local resorts.

These studies consisted not only of information obtained from internet resources, libraries, archives but also with a physical acquaintance with enterprises, visits to museums, monuments of architecture, culture, art; objects of resort infrastructure; conversations with experts from various fields of science, culture, entrepreneurship, all of this convinced the organizers of the seminar to expand the range of functions at the renovation facility.

This decision regarding the renovation of the salt factory was supported by the chief architect of Drohobych, Ihor Petranych. At a meeting in the City Council on December 15, 2020, he familiarized the participants of the seminar with the state on the architecture of the city and the prospects and directions of development of the newly formed Drohobych united community, the area of which has increased tenfold. He emphasized that he sees the development of the community, first of all, in the revival and introduction of the city's industry in all possible ways. This can be done not by renovating individual enterprises, but by complex strategic activities in relation to the city's industry as a whole and intensive (not extensive) permanent measures. It should be done with the revival of social and cultural infrastructure, with the use of existing, partially operating or non-operating buildings of industrial architecture, with an adaptation of public, industrial, commercial, residential functions and objects.

Based on the results of the seminar, preliminary clauses were developed. From them, projects created by Lviv students later showed up. From a wide range of proposals for the renovation of buildings and territories of the salt factory, students decided on the following: the first is the renovation of buildings and territories exclusively as an enterprise; the second is the implementation of cultural and artistic objects into the salt facility environment; third - buildings that had a health-improving and therapeutic function were added to the saltworks' facilities; fourth - combined projects - production, recreation, treatment.

In all 11 projects, the authors preserved buildings in one way or another and developed technological functions of salt production.

In the project of Student A. Dereshevska, it was proposed to restore all the objects of the salt factory, dividing the production territory into two parts. In the first one, leave the restored saltworks facilities - a brine mine, a brine pump building and pipelines, settling tanks, black buildings, but adding equipment and changes to the technological process, installing some of the pipes on the surface, making them transparent and even illuminated. So that you can track the movement of brine, make some settling tanks and tanks transparent so that you can see the process not only from above, but also from the inner side. In the second part, the author offered a multifunctional space on the western side of the complex for organizing fairs for the sale of various volumes of salt, products, medicines, and other products that contain salt, and premises for the sale of such products, and buildings for conducting master classes. (Fig. 2, a).

A whole group of students developed objects with a cultural and artistic function at the salt factory. It was Yu. Yanul, A.-M. Makaryk, V. M. Nahirnyak, A. Vovk.

In the project of V. M. Nahirnyak, in addition to industrial facilities, the salt factory was supposed to be enriched with buildings for cultural and artistic activities. They are named after prominent Drohobych artists known in Europe - Bruno Schultz, Efraim Moshe Lilien, Mauritius Gottlieb - in the form of not only memorial objects but also places of creativity of contemporary artists of the city and youth of the local art school. V. M. Nahirnyak designed the Art Center named after Bruno Schultz, which consisted of 3 parts: a studio workshop in the rebuilt ruins of the "new" cooking craft No. 2, a newly designed Exhibition Building for various art exhibits, and a foyer-communication that connects both spaces and has the 
appearance of a transparent parallelepiped. In the spaces of the studio, the author designed blocks in which the stages of the creation process should be shown in the form of films (Fig. 2,b).

The development of the complex was supplemented by the developments of student A.-M. Makaryk, who designed in the renovation space a co-working named after Efraim Moshe Lilien and Mauritius Gottlieb, a hotel for artists and art workshops. According to the author, the renovation of the salt factory with the completion of these objects, with the dedication of the famous European graphic artist Lilien and the painter Gottlieb, will make the salt factory even more iconic and historical coordinate. They are providing all visitors with the opportunity not only to self-realize in the proposed modern objects, the contours of which resemble restored industrial buildings, but should attract to this place, in addition to artists, both residents and tourists. Similar to the idea of the authors of the previous two projects are the proposals of student A. Vovk, who, in addition to the restoration and reconstruction of objects in which the salt-making process should take place, and the creation of multifunctional park space within the salt-making site, proposed to build a cultural and educational centre in the form of a salt crystal (Fig. 2,c). With the current exhibition "Salt way", dedicated to salt mining in Drohobych, Ukraine, Europe and the world, the salt phenomenon for the creation of human civilization on the first level of the centre is highlighted. As well as a variety of spaces and premises of a cultural and recreational nature on the second floor.

In their projects, O. Boyko, K. Ivashchuk, and A. Kushnir developed ideas for introducing a healthimproving and therapeutic function to the salt factory environment both in the open air and in specialized buildings. All three designers adopted the general concept of reviving the salt pond as a place for receiving salt mud baths in the northern part of the salt factory territory, and creating a game sports centre in the northern part, and thought about the need to create a spa centre, having adapted and rebuilt the ruins for this purpose, which should have been the "boiling" craft No. 2 and the building of the salt stand No. 1, which has lost its function. It was in this building that student $\mathrm{O}$. Boyko proposed to create a salt pool and inhalation halls with minimal reconstructive means - partial replacement of wooden enclosing structures with glass ones in metal stained glass windows. The placement in the south-western corner of houses for those who are treated with salt, according to the author's idea, can grow into a wellness centre at the salt factory. According to the idea of K. Ivashchuk, the ruin of the "boiling craft No. 2" is easy to turn into a healthy food restaurant, during which visitors on the first and second floors will be able to receive, at the same time, inhalations from the salt pool, which the author suggests placing in minus marks, on the first floor. According to the project of A. Kushnir, the Drohobych salt factory, in addition to a purely industrial function, could get the features of a spa resort, with salt baths, massage rooms, houses for those who are treated with salt, a cafe, a restaurant, a sports centre, etc. (Fig. 2, d). A universal project for the renovation of the saltworks space in the form of a park was proposed by Y. Yanul. According to her idea, sections of the park offer something for every visitor. At the main entrance near the pond, the author designed an amphitheatre and a stage. A variety of festivals, conferences and concerts can be held on the main square. In the northern part of the park, there should be an active recreation area with sports grounds for various sports, for people of all age categories. Designed football and volleyball courts, tennis and badminton courts. In the southern and most peaceful part, recreational areas are designed. The main axis of the plot directs visitors to the greenhouse, which is located in the ruins of the villa, the walls of which work as screens for watching movies. The author offers all this as an addition to the main function of the salt factory.

Interesting renovation ideas also took place in other projects of the seminar participants.

Calculations and macroeconomic modelling of the implementation of the proposed renovation projects of old industrial facilities, the transformation of some of them into tourist attractions, industrial sites, indicate the possibility of a significant increase in revenue to the budgets of the above-mentioned communities, turning them from subsidized to self-sufficient, which is extremely important in the conditions of military aggression in the east of Ukraine and losses of income from quarantine restrictions due to the COVID-19 pandemic. 

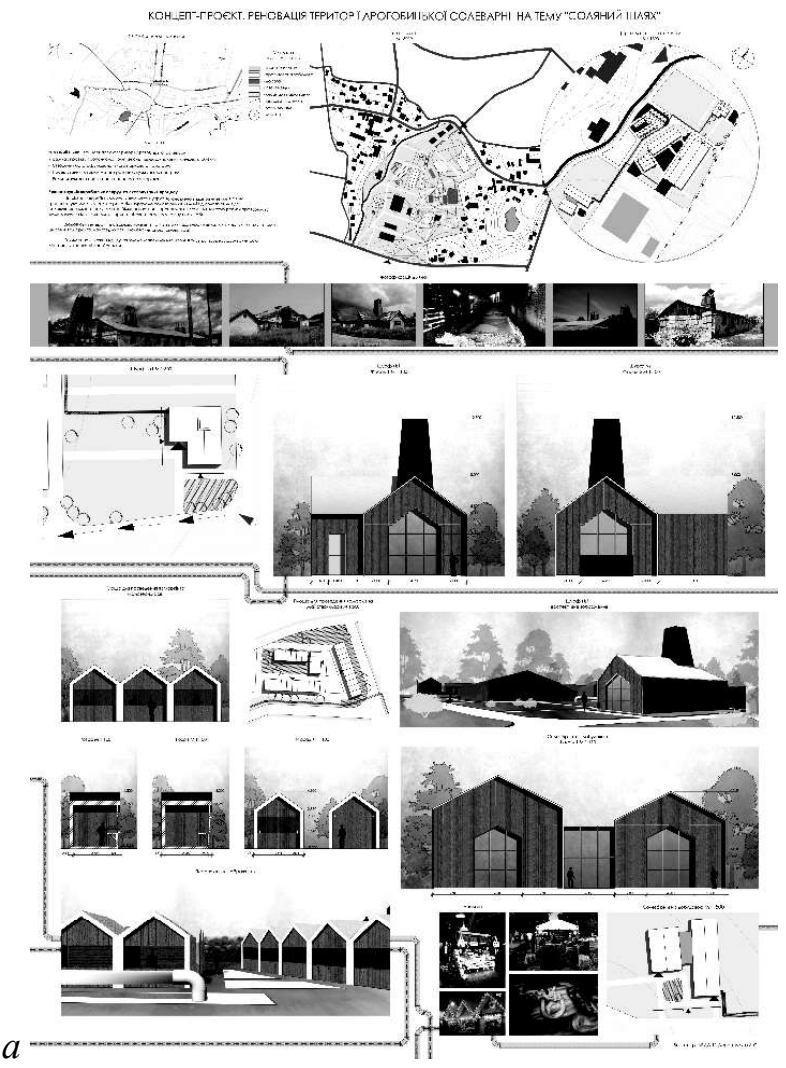

$a$

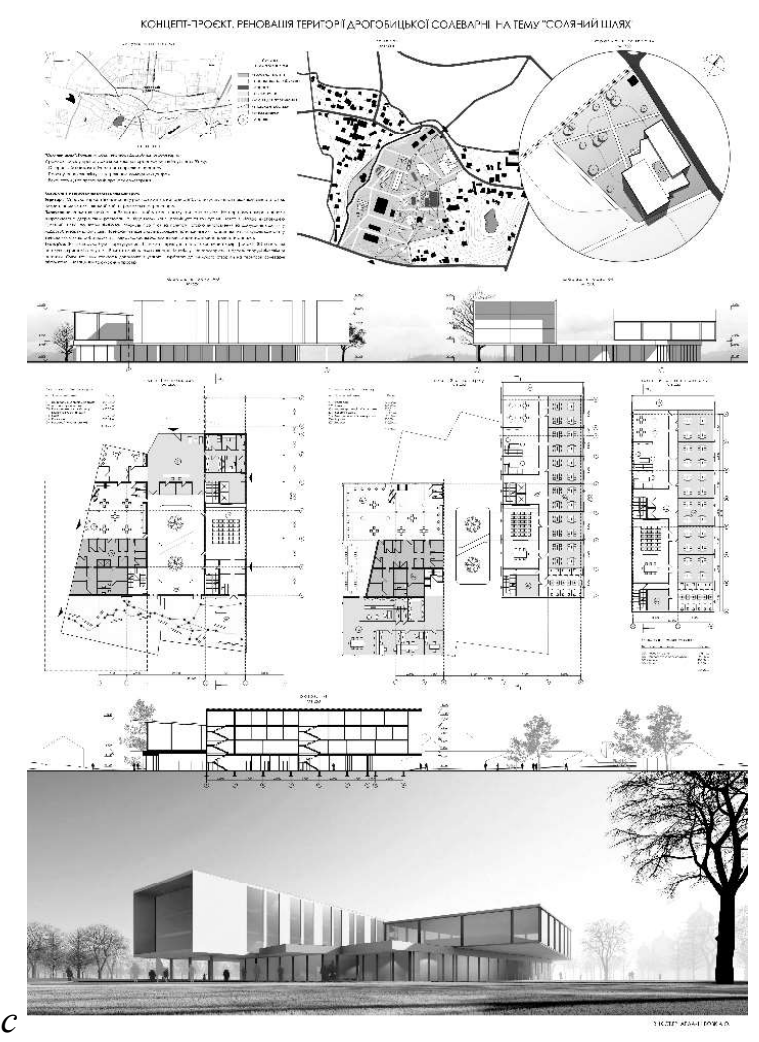

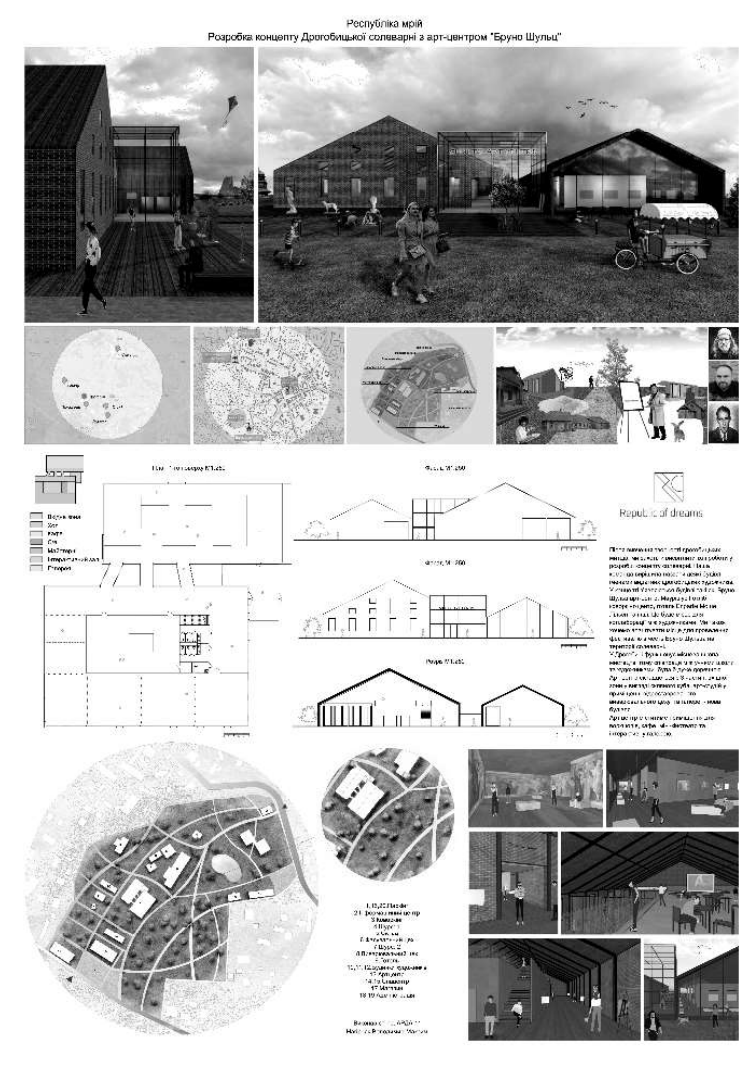
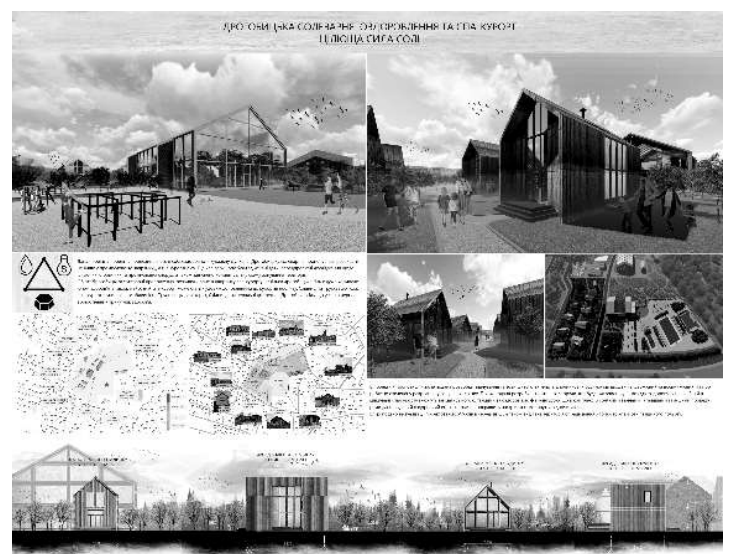

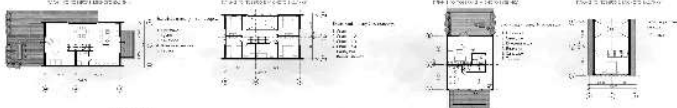

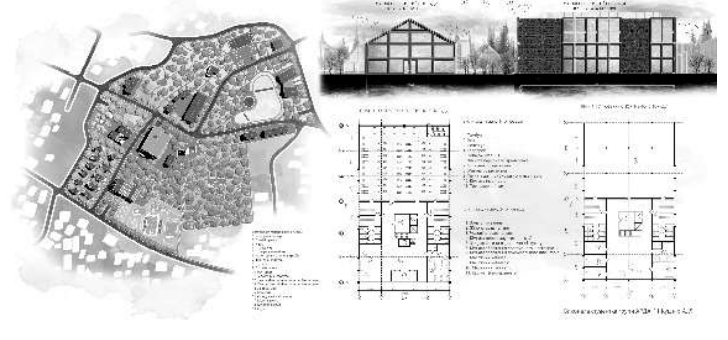

Fig. 2. Projects-proposals for the renovation of a salt factory in Drohobych by students

of the Department of Architectural Environment Design: a. A. Dereshivska; b. V.-M. Nahirnyak;c. A. Vovk; c. A. Kushnir Archive of the Department of Architectural Environment Design 


\section{Forecast of growth of revenue parts of budgets of territorial communities from the introduction of architectural and spatial planning, mln. UAH}

\begin{tabular}{|l|c|c|c|}
\hline \multicolumn{1}{|c|}{ Name of the territorial community } & 2021 & 2025 & 2030 \\
\hline Drohobych & 805.6 & 1300.0 & 2000.0 \\
\hline Truskavets & 270.0 & 450.0 & 900.0 \\
\hline Boryslav & 367.6 & 500.0 & 1000.0 \\
\hline Skhidnytsa & 115.1 & 250.0 & 450.0 \\
\hline Total & 1558.3 & 2500.0 & 4350.0 \\
\hline
\end{tabular}

The calculations also included achieving a sustainable agglomeration effect from the implementation of inter-municipal cooperation projects, for example, joint tourist and recreational routes, projects for the protection of forest ecosystems and biodiversity, water supply and sanitation, and so on.

\section{Conclusions}

1. During the conceptual preparation for the seminar "Magical salt cities", its participants found that in Europe and the world, in the practice of rehabilitation of industrial architecture, trends are developing in the formation, based on such buildings, of a larger range of industrial, public, commercial and residential functions and objects.

2. Same way as in the world, in Drohobych were formed two main groups of industrial facilities - objects of great historical value that can be identified as monuments of industrial architecture, and standard, unified serial industrial buildings and structures. Both require their rehabilitation methods, which should be tested and confirmed by search and experimental design.

3. In their 4 clausurs and 11 search projects, students of Lviv Polytechnic developed the principles of architectural and functional rehabilitation of the saltworks as follows: maximum preservation and imitation of the structural and planning structure of remained historical buildings; partial or complete change in the planning structure of those buildings that have become ruins. There were developed projects of buildings of a universal nature or other nomenclature in modern structures and with modern technological equipment, with the predominant preservation of silhouettes in the expanses and environment of the salt mill, which were formed for many years. Design of landscapes, small forms, equipment, colouristic and textures of the entire environment, the modern appearance of which was based on historical analogies.

\section{References}

Anisimova M.V., 2018. Ekonomichne planuvannya operaciinoi diyalnosti pidpriemstva / I. B. Skvorcov, M. S. Psui, L. R. Shved, M. V. Anisimova // Monografia. L'viv : Vid. "Magnolia”, S. 451-452.

Alexander Bouryak, Nora Lombardini, 2015. Social and cultural fundamentals of city development: Textbook. Kharkiv : “Operativnaya polygrafia". P. 36.

Vershinin V. I., 2006. Evolucia arhcitekturi promislovih sporud. Odesa : Astroprint. C. 135.

Vitaliy Dorofeyeyv, Rositsa Nikiforova, 2015. Principles of administrative decisions in city development. Textbook. Kharkiv : "Operativnaya polygrafia”. P. 25-28.

Ivanov-Kostec 'kii S. O., 2011. Principi arhitekurno-funkcional noi reabilitasii istorichnih promislovih budivel ta sporud: dis. ... kand. arh. : 18.00.01. Lviv. $17 \mathrm{~s}$. 
Proskuryakov V., Ivanov-Kostetskyi S., Grgic A., 2016. Typology of settelement and economic management: Textbook. Dnipro : S. P.Blyzniuk. P. 120.

Proskuryakov V. I., 2019. Pro futuristychni proekti Prikarpats'ka - ostanniogo "mista maibutniogo" Ukraini XXIs. / naukovii jurnal "Visnik Nacional 'nogo universitetu "Lvivska Politehnika", "Seria Arhitektura. T. 1, Specvipusk 2. C. 50-62.

Proskuryakov Viktor, 2013. The educational exploring, educational contest, contesting progecting experience of Lviv architectural school in 2013 / V. I. Proskuryakov, B. V. Goy // Srodowisko Mieskaniove: dom i osiedle jutra. Czesc II. No. 12. P. 92-98.

Fit’o A., 2019. Innovaciinii Prikarpats 'k maibutn`ogo zamist' “starogo” L`vova / Adrian Fit’o, Viktor Proskuryakov //RIF Lviv : Vid. Tov. "Reklamno-inform. Agen. Ria Lviv". Kiiv : Tov. "Art studiya druku”. No. 7. S. 8-9.

Cherkasova E. T., Lopatko V. M., Lombardini N., 2015. Renovation and revalorizaition of architectural objects: Textbook. Kharkiv : KhNUCEA, p. 48-50.

Mizina I. V., 2016. Financial decentralization and its impact on the local system Finance of Ukraine [online] Available at: https://core.ac.uk/download/pdf/233892467.pdf

Promislovist (informacia pro perelik pidpriemstv-eksporteriv mist Drohobicha ta Stebnika) Drohobic 'ka mis`ka Rada [online] Available at: https://drohobych-rada.gov.ua/\%D0\%B5\%D0\%BA\%D0\%BE\%D0\%BD\%B0\%BE\%D0\%BC\%D1\%96\% D0\% BA\%D0\%B0/promislovist/

Concept of reforming local self-government and territorial organization of power in Ukraine [online] Available at: https://zakon.rada.gov.ua/laws/show/333-2014-\%D1\%80\#Text

KMU 2020, Order about the statement of the perspective plan of formation of territories of communities of the Lviv region, 2020. [online] Available at: https://www.kmu.gov.ua/npas/pro-zatverdzhennya-perspektivnogo-planu-formuvannyateritorij-gromad-lvivskoyi-oblasti-i270520-624

Drohobych district 2020. [online] Available at: https://decentralization.gov.ua/newrayons/ 1362/communities

\author{
Віктор Проскуряков ${ }^{1}$, Сергій Іванов-Костецький ${ }^{2}$, \\ Андріан Фітьо ${ }^{3}$, Марія Анісімова ${ }^{4}$ \\ ${ }^{1}$ Проф., д-р арх., зав. кафедри проектування архітектурного середовища \\ Національний університет “Львівська політехніка", Львів \\ e-mail: viktor.i.proskuriakov@1pnu.ua \\ orcid: 0000-0003-1022-8984 \\ ${ }^{2}$ Ст. викл., канд. арх., кафедри проектування архітектурного середовища \\ Національний університет "Львівська політехніка", Львів \\ e-mail: serhii.o.ivanov-kostetskyi@lpnu.ua \\ orcid: 0000-0002-6047-609X \\ ${ }^{3}$ NGO "AC "EXPERT-GROUP" \\ e-mail: expertlviv@gmail.com \\ ${ }^{4}$ Асист., канд. екон. наук, кафедри економіки підприємств та інвестииій \\ Національний університет "Львівська політехніка", Львів \\ e-mail: mariia.v.anisimova@lpnu.ua \\ orcid: 0000-0002-1447-0930
}

\title{
АРХІТЕКТУРНІ, ЕКОНОМІЧНІ, МЕНТАЛЬНІ ЧИННИКИ ВІДРОДЖЕННЯ ІСТОРИЧНИХ ПРОМИСЛОВИХ ОБ'ЄКТІВ В УМОВАХ ФОРМУВАННЯ ТЕРИТОРІАЛЬНИХ ГРОМАД УКРАЇНИ
}

(на прикладі ремонту соляного заводу у Дрогобичі)

\footnotetext{
Анотація. У статті висвітлено шлях та фактори, що впливають на відродження історичних пам'яток на прикладі реконструкиї соляного заводу у Дрогобичі Дослідження фаз міських центрів життя вченими світу показало, що міста можуть опинитися у важкій ситуаиії та впадати у депресію не від застою та руйнування культурних цінностей та об'єктів культурної спадщини, а від спадщини та промислових об'єктів. До таких міст в Україні належить місто Дрогобич, де основні підприсмства припинили свою діяльність або функиіонують частково.

У Дрогобичі, як і в багатьох європейських містах, є історичні промислові підприємства, відомі в усьому світі. Пери за все, це солезавод, м'ясокомбінат, нафтопереробний комплекс "Полімін", нині - "Галичина" тощо, які можуть $i$
} 
повинні стати координатами пошуку районів оновлення, ревалоризаиії, реабілітаиії історичних пам'ятників промислової архітектури.

Для вирішення цих проблем 8-17 грудня 2020 року в Украйні відбувся семінар “Чарівні соляні міста", ініџійований викладачами та студентами Технічного університету в Кайзерслаутерні, Німеччина, та Начіональним університетом Львівської політехніки, студентами-архітекторами, експертами в галузі економіки, екології та географії.

Зі списку об'єктів було обрано соляний завод у Дрогобичі, відомий як підприємство з ХІV століття. Після роботи в групах українських та німецьких студентів над обстеженням солеварних підприємств, дослідженнями у галузі видобутку солі в Свропі та Україні, дослідженнями різних методів оновлення історичних промислових об'єктів, учасниками семінару було обрано 4 напрямки:

1 - ремонт будинків виключно як підприємство;

2 - передача об'єктів культури та мистечтва на соляний завод;

3 - об'єкти здоров'я та медичної функиії;

4 - комбіновані бази відпочинку та виробництва. Розроблено 11 навчально-пошукових проектів. Ці проекти будуть підготовлені у формі виставки у 2021 рочі в приміщенні Дрогобиџької міської ради.

Ключові слова: архітектурні, економічні, ментальні фактори; відродження; історичні, типові, уніфіковані, серійні, промислові будівлі Дрогобича. 